\title{
Refuge
}

Canada's Journal on Refugees

revue canadienne sur les réfugiés

\section{Children of the Camp: The Lives of Somali Youth Raised in Kakuma Refugee Camp, Kenya, by Catherine-Lune Grayson}

\section{Anna L. Jacobsen}

Volume 34, Number 2, 2018

URI: https://id.erudit.org/iderudit/1055589ar

DOI: https://doi.org/10.7202/1055589ar

See table of contents

Publisher(s)

Centre for Refugee Studies, York University

ISSN

0229-5113 (print)

1920-7336 (digital)

Explore this journal

Cite this review

Jacobsen, A. (2018). Review of [Children of the Camp: The Lives of Somali Youth Raised in Kakuma Refugee Camp, Kenya, by Catherine-Lune Grayson]. Refuge, 34(2), 156-157. https://doi.org/10.7202/1055589ar

This document is protected by copyright law. Use of the services of Erudit (including reproduction) is subject to its terms and conditions, which can be viewed online.

https://apropos.erudit.org/en/users/policy-on-use/ 


\section{Children of the Camp: The Lives of Somali Youth Raised in Kakuma Refugee Camp, Kenya $\sim$ \\ Catherine-Lune Grayson \\ New York: Berghahn Books, 2017, 246 pp.}

C hildren of the Camp is an ambitious and timely ethnographic approach to understanding the experiences of Somali youth who have lived all or most of their lives in a refugee camp in Kenya. The circumstances leading to their protracted refugee status have tragically become increasingly common, so while her work is about the Somali youth experience in Kakuma specifically, Dr. Grayson highlights frustrated creativity and enduring stasis that could lend insight into the experiences of displaced youth in many different contexts globally.

Her detailed attention to infrastructural, legal, and logistical challenges and options faced by these Somali youth, clearly drawing on her years of experience working within the world of refugee and humanitarian aid and resettlement, contextualize her ethnographic attention to the voices of these young people. Further, her focus on young people specifically helps to fill a literature about a portion of the population that gets far too little attention.

One of the most exciting aspects of her argument, for me, was how she implicitly constructed Kakuma itself as a protagonist in the autobiographical narratives these youth created for themselves and their communities. Kakuma, as a foster parent of sorts, was constantly both explicitly and implicitly engaged in a dialogue with these young people as they narrativized their senses of self and, borrowing from Martin Heidegger, their being-in-the-worldness. In doing so she avoided and at certain moments outright challenged the often arboreal representations of "the refugee": rootless, ungrounded, etc. The danger in doing so, as she points out, is to strip the creativity and self-construction constantly undertaken by youth as they negotiate a somewhat nostalgic remembering of the past, an imagined future of becoming, and a present that is not fulfilling many promises. Importantly, she does this without over-stating this agency. As Lila Abu-Lughod reminds us, every act of agency is a diagnostic of power and of the structures in which that act is performed. Dr. Grayson does this well.

In situating Kakuma as a protagonist rather than simply a location, Grayson shows how the often conflicted ways people viewed the space were not inherently contradictory. Like a foster parent, Kakuma was supposed to offer a temporary refuge with the hopes that a more permanent home could be found (or returned to) for the children. Foster homes are not designed to be durable solutions. Foster parents usually mean well but are often strait-jacketed by bureaucratic limitations and resources. Children who are placed under these temporary protections can feel a combination of relief, uncertainty, and the situational empowerment of knowing the placement should be temporary, and a not uncommon combination of feeling safe and untrusting.

It is logical, then, when viewing the refugee young person as in a dialogue of sorts with Kakuma, to expect her to undertake a complex and non-linear approach to narrativizing her own autobiographical self vis-à-vis the only "home" she has really known. But truly "becoming," as Grayson states clearly, requires a movement out of that home and a severing of that relationship in the future present. Grayson does this especially well in chapters 7 and 8 when she shows how the young people with whom she worked represent themselves (in selfportraits and in life-narratives) and how they imagine future possibilities in their own photos and words. These are also the chapters with the richest ethnographic data and descriptions. She cultivates a deeply critical perspective of current humanitarian and refugee-based policies and practices that offer a category of being, "refugee," as either a threat or a victim without acknowledging the agency and creativity constantly employed by the young person in everyday ways.

By focusing on these youths' individual and collective engagement with Kakuma-the complimentary and the critical-especially as these young people have known life only in camps, Grayson offers insight into the sometimes puzzling ways these Somali youth have come to understand their lives and place in the world. They are nostalgic for and have included memories of a Somalia they have never known. They see their ability to "become" in an idealized and imagined elsewhere, but that elsewhere was made possible because of Kakuma.

The challenges Grayson faced methodologically working in this context and with a population that has been socialized into an uncertain, often violent, and untrustworthy world were likely not small. I do wonder about how her entrée into the community potentially affected some of the ways people attended to issues such as insecurity or violence. I do not doubt the veracity of those claims but, as someone with professional attachments to aid organizations, I wonder if some 
of the themes characteristic of "life in Kakuma" might have been chosen by her interlocutors on the basis of that role.

I would have liked to see more of the youths' voices and ethnographic detail in earlier chapters to further humanize the argument she was making. While she provides very rich histories of the migration process and descriptions of institutional expectations, I wanted to hear about which artists local DJs were using to mix with Somali musicians on bootlegged and dubbed CDs and tracks. I wanted to hear a little about the latest wedding video that was circulating and that groups watched to admire, tease, envy, and criticize. When hearing about life in Kakuma I missed some of the everyday ways of being-not just the everyday violence. I wanted to read about the conversations these young people had with their families when they brought home or staged the photographs. I wanted to hear about how they went through the market to buy Eid el Fatr gifts and ingredients for the dinner.

I think Children of the Camp will be an important read for anyone interested in youth in protracted refugee status.

Anna L. Jacobsen is a lecturer in the Department of Anthropology, Washington University in St. Louis. The author may be reached at aljacobs@wustl.edu.

\title{
After the Flight: The Dynamics of Refugee Settlement and Integration
}

\author{
$\sim$ \\ Edited by Morgan Poteet and Shiva Nourpanah \\ Newcastle upon Tyne: Cambridge Scholars Publishing, 2018, 278 pp.
}

I ntegrating into a new locality can be very challenging for refugees. After the Flight: The Dynamics of Refugee Settlement and Integration focuses on some of the extreme barriers refugees face to their civic participation. Globally, a punitive political climate sees asylum seekers and refugees demonized as terrorists or welfare scroungers; alternatively, many are also belittled as vulnerable. Meanwhile, cuts to settlement services have been felt across the sector, characterized by a culture of mistrust and misunderstanding.

After the Flight is an edited volume that, after a brief introduction by the editors, is divided into eleven chapters-each depicting case studies of refugee integration in the Global North. The book develops its focus with attention to detailed empirical research and an emphasis on human agency. The chapters draw from extensive interviews and time spent with key individuals across the resettlement landscape from refugees to NGOs, academics, and immigration officials. Throughout, the attention to representing refugees as resourceful agents, who at times construct their own forms of integration, aims to counter patronizing depictions.

The book is divided into two main sections focused on the socio-cultural integration in host contexts and specific approaches to integration. In the first section, chapters trace the social and cultural landscape that refugees integrate to and from. Baker et al. emphasize the importance of acquiring citizenship for identity formation. The experience of Bhutanese Lhotshampa refugees moving from Nepalese refugee camps to small-town life in Newfoundland is fractured, with little sense of political and civic stability. Refugees develop what the authors refer to as a "cultural toolkit," drawing from past and present experiences to build an identity, which encompasses a sense of self-assurance. Malischewski, on the other hand, flips the focus to the vestiges of turbulence in the host country, in particular the many layers of segregation encountered by refugees resettling in Northern Ireland. Northern Ireland has seen a dramatic rise in asylum claims in recent years, but sectarian and local/foreigner divisions complicate integration. This chapter opens up interesting debates around integration when the norm is not to integrate but to live in sectarian divided neighbourhoods.

Following the focus on identity formation, the contributions move to develop questions of structure and agency. Nourpanah emphasizes the importance of seeing refugees as resourceful agents in her study of the integration of Afghan refugees in Halifax. Here refugees are subject to negative public stereotypes as fundamentalist Muslims or victims suffering loss and trauma. Nourpanah considers how refugees respond to the matrix that they find themselves fitting into, giving a fuller picture of people as creative and skilled workers. MacLaren et al. also provide an important critique of government policy, underlining the crucial role of networking among Karen refugees from Burma resettled in Australia. Refugees also encounter a toxic political discourse in Australia. The authors make specific recommendations for settlement agencies, including understanding people's cultural particularities and the importance of forging a culture of welcome. Finally, Ward turns the mirror on academics, arguing that they help shape the problematization of refugees. She raises important concerns, pointing out that academics tend to emphasize refugee vulnerability or focus research on 